\title{
Effect of the addition of wheat fiber and partial pork back fat on the chemical composition, texture and sensory property of low-fat bologna sausage containing inulin and oat fiber
}

\author{
Andrea Carla da Silva BARRETTO ${ }^{1 \star}$, Maria Teresa Bertoldo PACHECO², \\ Marise Aparecida Rodrigues POLLONIO ${ }^{3}$
}

\begin{abstract}
The objective of this work was to study the effect of adding wheat fiber and partial pork back fat on the quality characteristics of bologna sausage. The compound central rotating design was used with treatments containing fixed levels of inulin (5\%) and oat fiber (1\%) and variable levels of wheat fiber $(0-4 \%)$ and pork back fat $(0-10 \%)$. The $\mathrm{pH}$ and protein were similar in all the treatments, the fat was lower than the control treatment and the moisture content was higher than the control treatment (CF) without fibers. The wheat fiber increased the hardness and reduced cohesiveness and scores were given for overall impression. We found that it was possible to prepare low-fat bologna sausage with the addition of $6.58 \%$ fiber (5\% inulin, $1 \%$ oat fiber and $0.58 \%$ wheat fiber), whilst retaining good sensory acceptability, thus reducing the pork back fat levels by between 25 and $42.75 \%$.
\end{abstract}

Keywords: fat substitutes; wheat fiber; bologna sausage; microstructure.

Practical Applications: Bologna sausage was developed with 6,58\% added fibers and partial fat with good sensory acceptability.

\section{Introduction}

Meat and meat products occupy a prominent position in the human diet because of their high quality protein content, essential amino acids and good source of B-group vitamins, minerals and other ingredients. However, many consumers believe the consumption of meat and meat products is unhealthy because of their high animal fat, cholesterol and other ingredients (Hygreeva et al., 2014). The strategies for reducing the fat content in meat products follow two basic principles: the use of lean cuts that can increase the costs and/or the reduction of fat by the addition of water and other ingredients (Jiménez-Colmenero, 1996).

Due to their functional and technological properties, dietary fibers have been considered as a replacement for fat in several applications in the meat industry (Hughes et al., 1997; Cofrades et al., 2008; Cava et al., 2012; Ktari et al., 2014; Schmiele et al., 2015). The consumption of fiber has been recommended due to the health-beneficial physiological attributes, including the reduction in intestinal transit time, prevention of constipation and reduction of the risk of such chronic diseases such as cancer, Type 2 diabetes (through the reduction of the intestinal absorption of glucose) and cardiovascular diseases (through hypocholesterolemic effects and the control of obesity) (Sánchez-Alonso et al., 2007b; Borderías et al., 2005; Mendoza et al., 2001; Choi et al., 2014, Talukder, 2015).

From a technological viewpoint, the inclusion of soluble and insoluble fiber has mainly been done in restructured and emulsified products (Ayo et al., 2007; Fernández-Ginés et al., 2004; Turhan et al., 2005; Ktari et al., 2014) due to the excellent capacity of these products in retaining water and fat, a neutral odor, an improvement in the slicing of the products, hardness and the reduction in formulation costs. Despite these favorable properties, the substitution of fat through the addition of fiber is a great challenge in the development of meat products with regard to the preservation of palatability and shelf life. Fat contributes to the global acceptance of a meat product because it modifies the perception of flavor when influencing the release, intensity, migration and distribution of the compounds responsible for this attribute (Akoh, 1998). The partial substitution of animal fat by the addition of water and fiber can result in the release of liquids in the package during storage with a concomitant loss in hardness (Carballo et al., 1996; Claus et al., 1990). Cengiz \& Gokoglu (2005), Mansour \& Khalil (1999) and Keeton (1994), related that reformulation with fat substitutes can cause a decrease of the emulsion particle size, a darkening of the product, a loss of flavor and, subsequently, in palatability and a decrease in the shelf life from a microbiological point of view. Scanning electron microscopy was used to evaluate differences in meat emulsion structure and to compare them.

Bologna sausage is one of the main cooked emulsified meat products manufactured in Brazil and is appreciated in many countries. Its fat content usually varies between 20 and 30\%, which has motivated consumers to limit their purchases of this 
product. Several studies have reported on the use of insoluble and soluble fiber in emulsified products (Sánchez-Alonso et al., 2006, 2007a; Brooks et al., 2006; Piñero et al., 2008; Mansour \& Khalil, 1999; Steenblock et al., 2001; Warner \& Inglett, 1997; Cava et al., 2012; Yang et al., 2007), highlighting their technological and prebiotic properties. The objective of this study was to determine the effect of the addition of wheat fiber and partial pork back fat in the chemical composition, texture and sensory properties of low-fat bologna sausage which already contains some fiber ( $5 \%$ inulin and $1 \%$ oat fiber).

\section{Materials and methods}

\subsection{Materials}

Lean beef ( $70.10 \%$ moisture content and $5.95 \%$ fat content) and pork back fat (19.32\% moisture content and $78.76 \%$ fat content) were obtained from the local slaughterhouse with appropriate quality assurance. All of the subcutaneous, intramuscular fat and visible connective tissue from the lean meat and pork back fat were removed and the resulting products were minced through a $5 \mathrm{~mm}$ and $8 \mathrm{~mm}$ plate, respectively. The raw materials were then placed in polythene bags, vacuum sealed (Selovac CV60, $70 \mathrm{cmHg}$ ) and stored at $-18^{\circ} \mathrm{C}$ until required, for a maximum of 12-18 $\mathrm{h}$. The following non-meat ingredients were used: wheat fiber Vitacel WF200 (JRS \& Söhne Inc., São Paulo, Brazil), with a minimum content of $94 \%$ dietary fiber, oat fiber Vitacel HF600 (JRS \& Söhne Inc., São Paulo, Brazil), with 93\% insoluble fiber and a maximum content of $3 \%$ soluble fiber, and soluble dietary fiber, Raftiline HPX (Clariant, São Paulo, Brazil) and inulin with high performance and extracted from chicory, composed of a mixture of fructose polymers, with a polymerization degree ranging from 2 to 60 . The condiments and additives described in the formulation were provided by Kienast \& Kratschmer Ltda (São Paulo, Brazil).

\subsection{Experimental design}

A complete factorial design was used to assess the influence of wheat fiber and partial addition of pork back fat on the technological and sensory properties of the cooked emulsified meat product (bologna sausage). Therefore, the independent variables and their variation levels were the wheat fiber, WF 200 Vitacel (0-4\%), and pork back fat (0-10\%). The experimental design resulted in 12 treatments ( 4 factorial, 4 central and 4 axial) and a control treatment, with the addition of $20 \%$ pork back fat but without the addition of fibers, for a total of 13 treatments. The composition of the batter mixtures is shown in Table 1; the encoded and real levels are shown in Table 2. The dependent variables were: hardness, cohesiveness and overall impression. In this study, $10 \%$ pork back fat, $1 \%$ oat fiber and $5 \%$ inulin were used in the 12 treatments prepared, based on the sensory properties of the bologna sausage with reduced fat content amended with fiber as reported in a previous study (Barretto \& Pollonio, 2009).

Statistical Analysis System Institute (1999) was used to assess the results of the factorial design, to visualize the graphics of the response surface and analyze the effects was used to perform
ANOVA. The data were fitted to a second order equation (Equation 1) as a function of the dependent variables, as follows:

$\mathrm{Y}=\mathrm{b}_{0}+\mathrm{b}_{1} \mathrm{X}_{1}+\mathrm{b}_{2} \mathrm{X}_{2}+\mathrm{b}_{12} \mathrm{X}_{1} \mathrm{X}_{2}+\mathrm{b}_{11} \mathrm{X}_{1}^{2}+\mathrm{b}_{22} \mathrm{X}_{2}^{2}(1)$

where $b_{n}$ represents the constant regression coefficients, $Y$ represents the dependent variable and $X_{1}$ and $X_{2}$ are the coded independent variables.

\subsection{Meat emulsion manufacturing}

Following the compositions shown in Table 1, to process the mixture, the lean beef plus salt and half of the ice was added to the cutter (Incomaf, Brazil) and comminuted for extraction of the myofibrillar proteins.

The additives, the non-meat ingredients and the remaining ice were added to the cutter, which was in continuous operation at low speed. When the temperature reached $6-7^{\circ} \mathrm{C}$, the fiber and pork back fat were added, again according to Table 1 . The final temperature of the batter was standardized to a maximum of $18^{\circ} \mathrm{C}$. The mixture was then stuffed into a polyamide plastic casing, accommodating approximately $1 \mathrm{~kg}$ of the product. The resulting product was cooked in steam ovens until the internal temperature was $72{ }^{\circ} \mathrm{C}$, and then cooled in running water for 30 minutes. The samples were stored under refrigeration until the time of analysis.

\subsection{Chemical analysis (protein, fat, moisture and $p H$ measurement)}

The moisture and protein content of the low-fat bologna sausage were determined according to the methodology described by the Association of Official Analytical Chemists (1995). The fat content was quantified by the method described by Bligh \& Dyer (1959). The $\mathrm{pH}$ value was measured using an MA 130 Metler $\mathrm{pH}$ meter with a penetration probe, in corresponding segments of each newly processed formulation. All of the measurements were performed in quadruplicate.

\subsection{Texture profile analysis (TPA)}

The influence of the addition of the wheat fiber and the partial addition of fat on the texture was analyzed using a TA xT2i texture analyzer (Texture Technologies Corp., Scarsdale, NY) within ten days of production. All of the samples were compressed to $30 \%$ of their original weight. Three slices of $20 \mathrm{~mm}$ thickness were used to obtain six bologna sausage rolls with $20 \mathrm{~mm}$ diameters and $20 \mathrm{~mm}$ lengths, and a P-35 probe was used (long shaft, normal basis). The results were obtained after the samples reached the ambient temperature.

The following parameters were determined: hardness $(\mathrm{N})$, the maximum force required to compress the sample; springiness $(\mathrm{cm})$, the ability of the sample to recover its original form after the deforming force was removed; cohesiveness, the extent to which the sample could be deformed prior to rupture (A2/A1, where $\mathrm{A} 1$ is the total energy required for the first compression and $\mathrm{A} 2$ is the total energy required for the second compression); chewiness $(\mathrm{N} / \mathrm{cm})$, and the work required to masticate the sample for swallowing (Mendoza et al., 2001). 
Table 1. The basic treatments of the bologna sausage in the full factorial design.

\begin{tabular}{|c|c|c|c|c|c|c|c|c|c|c|}
\hline \multirow[b]{2}{*}{ Ingredients } & \multicolumn{10}{|c|}{ Treatments (\%) } \\
\hline & F1 & $\mathrm{F} 2$ & F3 & $\mathrm{F} 4$ & $\begin{array}{l}\text { F5, F6, } \\
\text { F7, F8 }\end{array}$ & F9 & F10 & F11 & F12 & $\mathrm{CF}$ \\
\hline Lean beef meat & 60.0 & 60.0 & 60.0 & 60.0 & 60.0 & 60.0 & 60.0 & 60.0 & 60.0 & 60.0 \\
\hline Pork back fat & 1.45 & 1.45 & 8.55 & 8.55 & 5.0 & 5.0 & 5.0 & 0.0 & 10.0 & 20.0 \\
\hline Ice/Water & 23.67 & 20.83 & 16.57 & 13.73 & 18.7 & 20.7 & 16.7 & 23.7 & 13.7 & 11.7 \\
\hline Cassava starch & 5.0 & 5.0 & 5.0 & 5.0 & 5.0 & 5.0 & 5.0 & 5.0 & 5.0 & 5.0 \\
\hline Mix bologna sausage Kraki & 0.43 & 0.43 & 0.43 & 0.43 & 0.43 & 0.43 & 0.43 & 0.43 & 0.43 & 0.43 \\
\hline Sodium nitrite & 0.02 & 0.02 & 0.02 & 0.02 & 0.02 & 0.02 & 0.02 & 0.02 & 0.02 & 0.02 \\
\hline Sodium tripolyphosphate & 0.3 & 0.3 & 0.3 & 0.3 & 0.3 & 0.3 & 0.3 & 0.3 & 0.3 & 0.3 \\
\hline Salt & 2.5 & 2.5 & 2.5 & 2.5 & 2.5 & 2.5 & 2.5 & 2.5 & 2.5 & 2.5 \\
\hline Sodium eritorbate & 0.05 & 0.05 & 0.05 & 0.05 & 0.05 & 0.05 & 0.05 & 0.05 & 0.05 & 0.05 \\
\hline Inulin - Raftiline & 5.0 & 5.0 & 5.0 & 5.0 & 5.0 & 5.0 & 5.0 & 5.0 & 5.0 & - \\
\hline Wheat fibre Vitacel & 0.58 & 3.42 & 0.58 & 3.42 & 2.0 & 0.0 & 4.0 & 2.0 & 2.0 & - \\
\hline Oat fibre Vitacel & 1.0 & 1.0 & 1.0 & 1.0 & 1.0 & 1.0 & 1.0 & 1.0 & 1.0 & - \\
\hline
\end{tabular}

Table 2. Independent variable values and variance levels of the full factorial design.

\begin{tabular}{|c|c|c|c|c|c|}
\hline \multirow{2}{*}{$\begin{array}{c}\text { Independent } \\
\text { variables }\end{array}$} & \multicolumn{5}{|c|}{ Levels } \\
\hline & $\begin{array}{c}-\alpha \\
(-1.41) \\
\end{array}$ & -1 & 0 & 1 & $\begin{array}{c}+\alpha \\
(+1.41) \\
\end{array}$ \\
\hline $\begin{array}{c}\text { X1 }=\text { Wheat fibre } \\
\text { WF200 Vitacel (\%) }\end{array}$ & 0.00 & 0.58 & 2.00 & 3.42 & 4.00 \\
\hline $\begin{array}{c}\mathrm{X} 2 \text { = Pork back } \\
\text { fat }(\%)\end{array}$ & 0.00 & 1.45 & 5.00 & 8.55 & 10.00 \\
\hline
\end{tabular}

\subsection{Sensory evaluation}

The acceptability test was used to assess the degree of how much the consumers liked or did not like the mentioned products with regard to overall impression. The panel consisted of 30 non-trained tasters, all consumers of meat products and all students of the State University of Campinas, SP, Brazil, and who were initially familiarized with the terminology adopted. The panelists were instructed to cleanse their palates with water between the samples. All the samples were presented to the potential consumers in a monadic sequential way, using a nine-point hedonic scale $(1=$ extremely disliked and $9=$ extremely liked), in complete blocks divided into four sessions, as proposed by Macfie et al. (1989).

\subsection{Scanning electron microscopy}

Microscopic examination of the bologna sausage samples was performed, as described by Feng et al. (2003), with samples obtained by cutting $\left(2 \times 2 \times 7 \mathrm{~mm}^{3}\right)$ from the interior of the bologna sausage and fixed for $24 \mathrm{~h}$ at $4^{\circ} \mathrm{C}$ in a $0.1 \mathrm{M}$ phosphate buffer ( $\mathrm{pH}$ 7) containing $2.5 \%$ glutaraldehyde. Fixed samples were dipped in the $0.1 \mathrm{M}$ phosphate buffer $(\mathrm{pH} 7)$ for $10 \mathrm{~min}$ and then post-fixed for $5 \mathrm{~h}$ in $0.1 \mathrm{M}$ phosphate buffer $(\mathrm{pH} 7)$ containing $1 \%$ osmium tetroxide. The fixed samples were washed three times, each time with $0.1 \mathrm{M}$ phosphate buffer ( $\mathrm{pH} 7)$ for $10 \mathrm{~min}$, and dehydrated in an ethanol series $(30,50,70,95$, and $100 \%$ for $30 \mathrm{~min}$ each). The samples were further dehydrated by being submerged in absolute ethanol and then dried in warm air. The dried samples were mounted on copper sample holders, coated with gold (Sputter Coater SCD-050, Balzers), and examined under a Jeol - JSM - 5800 LV Scanning Microscope (Japan) with a $10 \mathrm{kV}$ accelerating voltage.

\section{Results and discussion \\ 3.1 Moisture, protein, fat and $\mathrm{pH}$}

The results obtained for the moisture, fat, protein and $\mathrm{pH}$ are shown in Table 3. The formulations presented protein contents nearing $12 \%$, as the only protein source was the meat. The results of the fat contents varied between the formulations and were related to the content added in the formulation. Talukder (2015) related that the addition of fibers can cause change in the $\mathrm{pH}$ of meat products. The addition of the fiber and pork back fat did not affect the $\mathrm{pH}$ values, which remained very similar between the treatments.

The moisture content of treatments was greater than the control treatment $(\mathrm{CF})$ without fibers $(\mathrm{P}<0.05)$. The moisture contents correlated with the quantity of water added in the different formulations, according to Table 1. In the treatments, when fibers were added, the fat was reduced and the water increased, but the quantity of meat was the same in all the treatments. Similar results were reported by Choi et al. (2009) and Schmiele et al. (2015), where the moisture content of meat emulsions were lower in those formulations with a greater addition of fat. Troy et al. (1999) and Mansour \& Khalil (1999) also report that formulations of beef burgers with the addition of fat substitutes had contained more moisture when compared with control samples.

\subsection{Analysis of the texture profile}

Some studies have shown that products with a lower fat content are firmer and can compromise the overall sensory quality according to the rheological properties of the substitute ingredients used (Keeton, 1994; Choi et al., 2009; García et al., 2002). It was observed in this study that the greater the quantity of added wheat fiber, the greater the hardness. The results of the 
Table 3. Results of the full factorial design for the moisture, fat, protein and $\mathrm{pH}$.

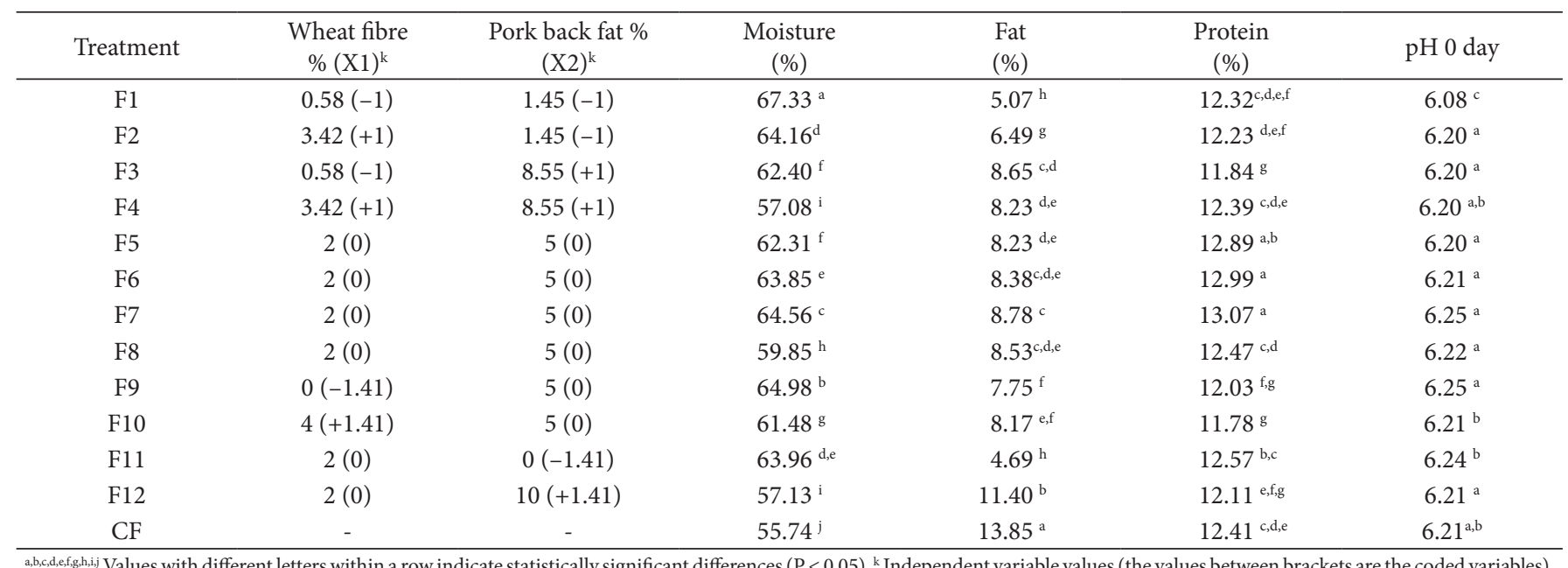

texture profile analysis are shown in Table 4. Only the linear effect of the variable wheat fiber was found to be significant $(\mathrm{p}<0.05)$. The pork back fat did not have any effect on the hardness of the studied levels $(0-10 \%)$, and the model obtained is as follows (Equation 2):

Hardness $=34.4852+8.6804 \times 1\left(R^{2}=0.7925\right)(2)$

The response surface for hardness with regard to the wheat fiber and pork back fat is shown in Figure 1a. The control formulation (with the addition of $20 \%$ pork back fat) obtained a lower value for hardness than those obtained with the design. These results are in accordance with those found by Cofrades et al. (2008), in which the different effects found for three different types of edible seaweeds on the properties of meat texture emulsions corresponded to the different proportions and compositions of the dietary fiber used. These authors also report that insoluble fiber can increase the consistency of meat products by forming an insoluble three-dimensional network that is capable of modifying the rheological property of the continuous emulsion stage.

Regarding the springiness, it was not possible to establish a mathematical model regarding the studied variables because no effect was significant $(\mathrm{p}>0.05)$. The analysis of variance was low $\left(\mathrm{R}^{2}=0.7011\right)$, and the $\mathrm{F}_{\text {calculated }}(2.81)$ was lower than the $\mathrm{F}_{\text {tabulated }}(4.39)$, so the values were not presented.

The cohesiveness was significantly lower in the samples with added fiber and a partial pork back fat reduction, as compared with the CF treatment, similar to the results of Choi et al. (2014) and Ktari et al. (2014), showing that the fat increased the cohesiveness when no fibers were added. Only the F1 treatment provided a result similar to the control formulation, when only $0.58 \%$ wheat fiber was added. The wheat fiber contributed significantly $(p<0.05)$ to the decrease of the cohesiveness. Figure $1 b$ provides the response surface for cohesiveness according to the wheat fiber and fat content. The model for this data is the following (Equation 3):

Cohesiveness $=0.7820-0.0331 \times \mathrm{x} 1\left(\mathrm{R}^{2}=0.8409\right)(3)$

The cohesiveness was decreased as the quantity of wheat fiber and pork back fat was increased. Mendoza et al. (2001) reported that the cohesiveness decreased with a reduction of the fat content.

The chewiness parameter was lower in the CF treatment. Similar results were found by Mendoza et al. (2001) and García et al. (2002), where the fiber significantly affected the chewiness of low-fat sausages. These results are expected because chewiness is the work required to masticate the sample for swallowing, and it is raised when fibers are added. It was not possible to establish a model in this study, because no effect was significant $(\mathrm{p}>0.05)$ and the coefficient of determination was low $\left(R^{2}=0.6893\right)$, so the values were not presented.

\subsection{Sensory analysis}

The results of the sensory analysis (overall impression) are presented in Table 4 . The wheat fiber contributed significantly $(p<0.10)$ to the decrease of the scores given for overall impression and the model obtained was the following (Equation 4):

Overall impression $=6.6923-0.5368 \cdot \times 1\left(\mathrm{R}^{2}=0.7294\right)(4)$

The coefficient of determination was satisfactory, showing that the wheat fiber must be used in small quantities as a substitute ingredient for fat, as its use implies a decrease in overall impression scores in emulsified products, such as bologna sausage, with $6 \%$ fiber previously added (5\% inulin and $1 \%$ oat fiber). And the partial addition of pork back fat in the studied levels $(0-10 \%)$ did not contribute to global impression scores. The addition of $4 \%$ of wheat fiber (F10) was significantly different from the CF treatment. The response surface for the overall 
Table 4. Results of the full factorial design for the TPA and sensorial analyses (scores).

\begin{tabular}{|c|c|c|c|c|c|}
\hline Treatment & $\begin{array}{c}\text { Wheat fibre } \\
\%(\mathrm{X} 1)^{j}\end{array}$ & $\begin{array}{c}\text { Pork back fat } \\
\%(\mathrm{X} 2)^{j}\end{array}$ & $\begin{array}{l}\text { Hardness } \\
\left(\mathrm{N} / \mathrm{cm}^{2}\right)\end{array}$ & Cohesiveness & Overall impression \\
\hline $\mathrm{F} 1$ & $0.58(-1)$ & $1.45(-1)$ & $27.53^{\mathrm{f}, \mathrm{g}}$ & $0.8228^{\mathrm{a}, \mathrm{b}}$ & $7.03^{a, b}$ \\
\hline F2 & $3.42(+1)$ & $1.45(-1)$ & $42.09^{\mathrm{a}, \mathrm{b}}$ & $0.7815^{\text {e,f,g,h }}$ & $6.60^{\mathrm{a}, \mathrm{b}}$ \\
\hline F3 & $0.58(-1)$ & $8.55(+1)$ & $34.60^{c, d, e}$ & $0.8019^{\mathrm{cdd}}$ & $6.60^{\mathrm{a}, \mathrm{b}}$ \\
\hline F4 & $3.42(+1)$ & $8.55(+1)$ & $38.24^{\mathrm{b}, c, \mathrm{~d}}$ & $0.7660^{\mathrm{h}, \mathrm{i}}$ & $6.3^{\mathrm{a}, \mathrm{b}}$ \\
\hline F5 & $2(0)$ & $5(0)$ & $32.84^{\mathrm{d}, \mathrm{e}, \mathrm{f}}$ & $0.7886^{\mathrm{d}, \mathrm{e}}$ & $6.73^{\mathrm{a}, \mathrm{b}}$ \\
\hline F6 & $2(0)$ & $5(0)$ & $39.57^{\mathrm{a}, \mathrm{b}, \mathrm{c}}$ & $0.7831^{\mathrm{e}, \mathrm{f}, \mathrm{g}, \mathrm{h}}$ & $6.87^{\mathrm{a}, \mathrm{b}}$ \\
\hline F7 & $2(0)$ & $5(0)$ & $34.29^{\mathrm{c}, \mathrm{d}, \mathrm{e}}$ & $0.7866^{\mathrm{de}, \mathrm{f}}$ & $6.37^{\mathrm{a}, \mathrm{b}}$ \\
\hline F8 & $2(0)$ & $5(0)$ & $31.21^{\mathrm{e}, \mathrm{f}}$ & $0.7699^{\mathrm{f}, \mathrm{g}, \mathrm{h}, \mathrm{i}}$ & $6.80^{\mathrm{a}, \mathrm{b}}$ \\
\hline F9 & $0(-1,41)$ & $5(0)$ & $32.32^{e, f}$ & $0.8071^{\mathrm{b}, \mathrm{c}}$ & $7.07^{\mathrm{a}}$ \\
\hline F10 & $4(+1,41)$ & $5(0)$ & $43.95^{\mathrm{a}}$ & $0.7683^{\mathrm{g}, \mathrm{h}, \mathrm{i}}$ & $6.07^{\mathrm{b}}$ \\
\hline F11 & $2(0)$ & $0(-1.41)$ & $32.19^{e, f}$ & $0.7853^{\mathrm{d}, \mathrm{e}, \mathrm{f}, \mathrm{g}}$ & $6.63^{a, b}$ \\
\hline $\mathrm{F} 12$ & $2(0)$ & $10(+1.41)$ & $41.59^{\mathrm{a}, \mathrm{b}}$ & $0.7624^{\mathrm{i}}$ & $6.53^{\mathrm{a}, \mathrm{b}}$ \\
\hline $\mathrm{CF}$ & - & - & $23.73^{\mathrm{g}}$ & $0.8268^{\mathrm{a}}$ & $7.20^{\mathrm{a}}$ \\
\hline
\end{tabular}
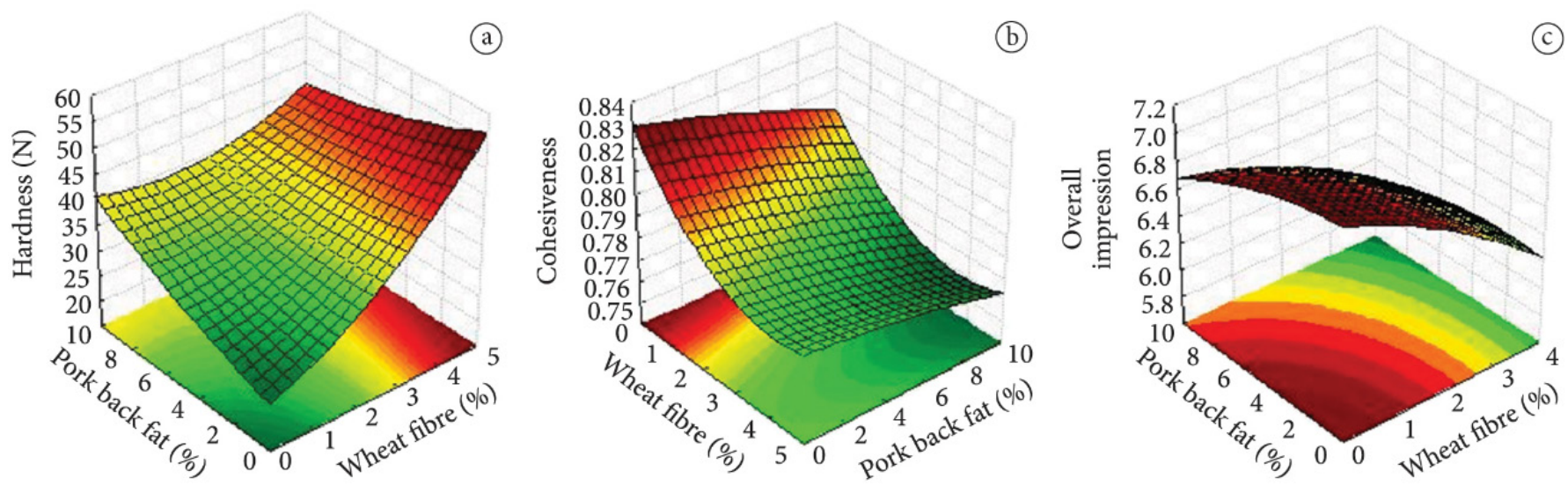

Figure 1. Response surfaces of the effects of wheat fibre and pork back fat on a) hardness, b) cohesiveness and c) overall impression.

impression due to the wheat fiber and pork back fat is shown in Figure 1c. The addition of $6.58 \%$ fiber ( $5 \%$ inulin, $1 \%$ oat fiber both previously added and $0.58 \%$ wheat fiber) and $11.45 \%$ pork back fat ( $10 \%$ previously added pork back fat $+1.45 \%$ as shown in Table 4 for F1) did not differ from the CF treatment, without the addition of fiber and with addition of $20 \%$ pork back fat.

Andrés et al. (2006) observed that a low bovine fat content $(0,2$ and $5 \%)$ did not affect the scores given for flavor, texture and global acceptance of low-fat chicken sausages. Troy et al. (1999) studied the effect of various mixtures on low-fat beef burgers and concluded that the flavor and texture are important attributes for acceptability and that no difference was found for the flavor in the studied mixtures.

\subsection{Scanning electron microscopy}

The bologna sausage formulations with higher scores (F1 and F9) for the overall impression and the CF treatment were prepared and subjected to scanning electron microscopy to assess the qualitative differences on the microstructure of the emulsions formed. Figure 2 shows the microstructures of these treatments (CF, F1 and F9).

The CF treatment was characterized as homogenous and there was a greater presence of fat globules (Figure 2-CF). A good uniformity in the fat globules was observed for F1, though with an uneven size (Figure 2-F1). Andrés et al. (2006) also found different sizes of fat globules in low-fat chicken sausages. Totosaus \& Pérez-Chabela (2009) found similar reports, additionally mentioning the greater presence of pores, as characterized by the higher water content in low-fat formulations. The presence of insoluble fiber (wheat and/or oat) is notable in Figures 2-F1 and F9 with the presence fiber bundles that are not observed in Figure 2-CF. It is likely that the soluble fiber was dispersed in the matrix and could not be identified in the microstructure. The presence of insoluble fiber throughout the fat globule perimeter indicates the participation of the stabilization of the interfacial film that wrapped the fat (Figures $2 \mathrm{a}$ and $\mathrm{b}$ ). These results may help to uncover the mechanism of meat emulsion formation in the presence of fiber and its behavior in the meat matrix. 

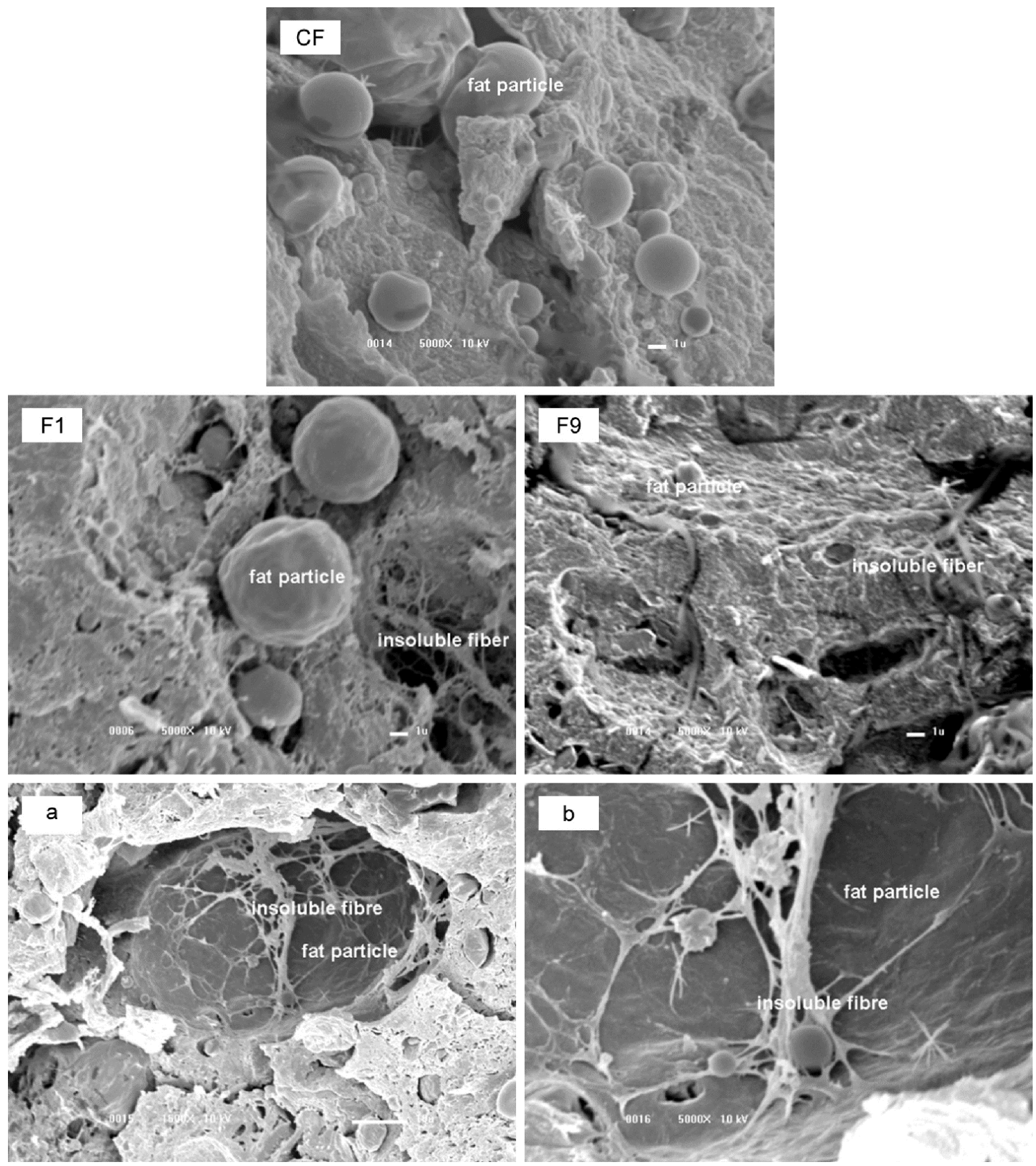

Figure 2. Scanning electron micrographs (magnification: 5000X) of bologna sausage with different treatments. CF $=$ control (no added fiber), $\mathrm{F} 1=0.58 \%$ wheat fiber and $1.45 \%$ pork back fat added, F9 $=0 \%$ wheat fiber and $5 \mathrm{~g} / 100 \mathrm{~g}$ pork back fat. a, b = F9 with $1500 \mathrm{X}$ and $5000 \mathrm{X}$ magnification (same figure).

\section{Conclusions}

The technological identity pattern of the bologna sausage was preserved with the substitution of $25 \%$ to $42.75 \%$ added pork back fat and with the addition of $0.58 \%$ wheat fiber (with the previous addition of $1 \%$ oat fiber and $5 \%$ inulin). The wheat fiber contributed to increase hardness and decreases in both cohesiveness and in scores given for the overall impression. By using scanning electron microscopy, it was possible to visualize the participation of the insoluble fiber in the formation of the interfacial film that wrapped the fat.

The bologna sausage with total addition of $6.58 \%$ fiber ( $1 \%$ oat fiber, $5 \%$ inulin and $0.58 \%$ wheat fiber) and $11.45 \%$ pork back fat (10\% addition of fixed plus the $1.45 \%$ addition in the treatment) produced scores for overall impression, hardness and cohesiveness similar to the control bologna sausage (CF treatment) with the $20 \%$ pork back fat addition and without 
the addition of fiber, showing the fibers can partially substitute fat in low-fat bologna sausage.

\section{Acknowledgements}

The authors would like to acknowledge the financial support from CAPES.

\section{References}

Akoh, C. C. (1998). Fat replacers. Food Technology, 52(3), 47-53.

Andrés, S. C., García, M. E., Zaritzky, N. E., \& Califano, A. N. (2006). Storage stability of low-fat chicken sausages. Journal of Food Engineering, 72(4), 311-319. http://dx.doi.org/10.1016/j.jfoodeng.2004.08.043.

Association of Official Analytical Chemists - AOAC. (1995). Official methods of analysis of the Association of Analytical Chemists. 15th ed. Washington: AOAC.

Ayo, J., Carballo, J., Serrano, J., Olmedilla-Alonso, B., Ruiz-Capillas, C., \& Jiménez-Colmenero, F. (2007). Nutritional profile of frankfurters formulated with added walnuts and with two different pork fat levels. Meat Science, 77(2), 173-181. http://dx.doi.org/10.1016/j. meatsci.2007.02.026. PMid:22061588

Barretto, A. C. S., \& Pollonio, M. A. R. (2009). Aplicação de fibras como substituto de gordura em mortadela e influência sobre as propriedades sensoriais. Higiene Alimentar, 23(171/175), 181-188.

Bligh, E. G., \& Dyer, W. J. (1959). A rapid method of total lipid extraction and purification. Canadian Journal of Biochemistry and Physiology, 37(8), 911-917. http://dx.doi.org/10.1139/o59-099. PMid:13671378

Borderías, A. J., Sánchez-Alonso, I., \& Pérez-Mateos, M. (2005). New applications of fibres in foods: addition to fishery products. Trends in Food Science \& Technology, 16(10), 458-465. http://dx.doi. org/10.1016/j.tifs.2005.03.011.

Brooks, S. P. J., Mongeau, R., Deeks, J. R., Lampi, B. J., \& Brassard, R. (2006). Dietary fibre in baby foods of major brands sold in Canada. Journal of Food Composition and Analysis, 19(1), 59-66. http://dx.doi. org/10.1016/j.jfca.2005.02.002.

Carballo, J., Fernandez, P., Barreto, G., Solas, M. T., \& Colmenero, F. J. (1996). Morphology and texture of bologna sausage as related to content of fat, starch and egg white. Journal of Food Science, 61(3), 652-655. http://dx.doi.org/10.1111/j.1365-2621.1996.tb13179.x.

Cava, R., Ladero, L., Cantero, V., \& Rosario Ramírez, M. (2012). Assessment of different dietary fibers (tomato fiber, beet root fiber, and inulin) for the manufacture of chopped cooked chicken products. Journal of Food Science, 77(4), C346-C352. http://dx.doi. org/10.1111/j.1750-3841.2011.02597.x. PMid:22352766

Cengiz, E., \& Gokoglu, N. (2005). Changes in energy and cholesterol contents of frankfurter-type sausages with fat reduction and fat replacer addition. Food Chemistry, 91(3), 443-447. http://dx.doi. org/10.1016/j.foodchem.2004.06.025.

Choi, Y. S., Choi, J. H., Han, D. J., Kim, H. Y., Lee, M. A., Kim, H. W., Jeong, J. Y., \& Kim, C. J. (2009). Characteristics of low-fat meat emulsion systems with pork fat replaced by vegetable oils and rice bran fiber. Meat Science, 82(2), 266-271. http://dx.doi.org/10.1016/j. meatsci.2009.01.019. PMid:20416740

Choi, Y. S., Kim, H. W., Hwang, K. E., Song, D. H., Choi, J. H., Lee, M. A., Chung, H. J., \& Kim, C. J. (2014). Physicochemical properties and sensory characteristics of reduced-fat frankfurters with pork back fat replaced by dietary fiber extracted from makgeolli lees. Meat Science, 96(2 Pt A), 892-900. http://dx.doi.org/10.1016/j. meatsci.2013.08.033. PMid:24200582
Claus, J. R., Hunt, M. C., \& Kastner, C. L. (1990). Effects of substituting added water for fat on texture, sensory and processing characteristics of bologna. Journal of Muscle Foods, 1(1), 1-21. http://dx.doi. org/10.1111/j.1745-4573.1990.tb00349.x.

Cofrades, S., López-López, I., Solas, M. T., Bravo, L., \& Jiménez-Colmenero, F. (2008). Influence of different types and proportions of added edible seaweeds on characteristics of low-salt gel/emulsion meat systems. Meat Science, 79(4), 767-776. http://dx.doi.org/10.1016/j. meatsci.2007.11.010. PMid:22063041

Feng, J., Xiong, Y. L., \& Mikel, W. B. (2003). Textural properties of pork frankfurters containing thermally/enzymatically modified soy proteins. Journal of Food Science, 68(4), 1220-1224. http://dx.doi. org/10.1111/j.1365-2621.2003.tb09628.x.

Fernández-Ginés, J. M., Fernández-López, J., Sayas-Barberá, E., Sendra, E., \& Pérez-Álvarez, J. A. (2004). Lemon albedo as a new source of dietary fiber: application to bologna sausages. Meat Science, 67(1), 7-13. http://dx.doi.org/10.1016/j.meatsci.2003.08.017. PMid:22061110

García, M. L., Dominguez, R., Galvez, M. D., Casas, C., \& Selgas, M. D. (2002). Utilization of cereal and fruit fibres in low fat dry fermented sausages. Meat Science, 60(3), 227-236. http://dx.doi.org/10.1016/ S0309-1740(01)00125-5. PMid:22063393

Hughes, E., Cofrades, S., \& Troy, D. J. (1997). Effects of fat level, oat fibre and carrageenan on frankfurters formulated with 5, 12 and 30\% fat. Meat Science, 45(3), 273-281. http://dx.doi.org/10.1016/ S0309-1740(96)00109-X. PMid:22061466

Hygreeva, D., Pandey, M. C., \& Radhakrishna, K. (2014). Potential applications of plant based derivatives as fat replacers, antioxidants and antimicrobials in fresh and processed meat products. Meat Science, 98(1), 47-57. http://dx.doi.org/10.1016/j.meatsci.2014.04.006. PMid:24845336

Jiménez-Colmenero, F. (1996). Technologies for developing low-fat meat products. Trends in Food Science \& Technology, 7(2), 41-48. http://dx.doi.org/10.1016/0924-2244(96)81327-6.

Ktari, N., Smaoui, S., Trabelsi, I., Nasri, M., \& Ben Salah, R. (2014). Chemical composition, techno-functional and sensory properties and effects of three dietary fibers on the quality characteristics of Tunisian beef sausage. Meat Science, 96(1), 521-525. http://dx.doi. org/10.1016/j.meatsci.2013.07.038. PMid:24013695

Keeton, J. T. (1994). Low-fat meat products-technological problems with processing. Meat Science, 36(1-2), 261-276. http://dx.doi. org/10.1016/0309-1740(94)90045-0. PMid:22061464

Macfie, H. J., Bratchell, N., Greenhoff, K., \& Vallis, L. V. (1989). Designs to balance the effect of order of presentation and first-order carryover effects in hall tests. Journal of Sensory Studies, 4(2), 129-148. http://dx.doi.org/10.1111/j.1745-459X.1989.tb00463.x.

Mansour, E. H., \& Khalil, A. H. (1999). Characteristics of low-fat beefburgers as influenced by various types of wheat fibres. Journal of the Science of Food and Agriculture, 79(4), 493-498. http:// dx.doi.org/10.1002/(SICI)1097-0010(19990315)79:4<493::AIDJSFA4 $>3.0 . \mathrm{CO} ; 2-5$.

Mendoza, E., García, M. L., Casas, C., \& Selgas, M. D. (2001). Inulin as fat substitute in low fat, dry fermented sausages. Meat Science, 57(4), 387-393. http://dx.doi.org/10.1016/S0309-1740(00)00116-9. PMid:22061711

Piñero, M. P., Parra, K., Huerta-Leidenz, N., Arenas de Moreno, L., Ferrer, M., Araujo, S., \& Barboza, Y. (2008). Effect of oat's soluble fibre ( $\beta$-glucan) as a fat replacer on physical, chemical, microbiological and sensory properties of low-fat beef patties. Meat Science, 80(3), 675680. http://dx.doi.org/10.1016/j.meatsci.2008.03.006. PMid:22063581 
Sánchez-Alonso, I., Haji-Maleki, R., \& Borderias, A. J. (2006). Effect of wheat fibre in frozen stored fish muscular gels. European Food Research and Technology, 223(4), 571-576. http://dx.doi.org/10.1007/ s00217-005-0242-4.

Sánchez-Alonso, I., Haji-Maleki, R., \& Borderías, A. J. (2007a). Wheat fibre as a functional ingredient in restructured fish products. Food Chemistry, 100(3), 1037-1043. http://dx.doi.org/10.1016/j. foodchem.2005.09.090.

Sánchez-Alonso, I., Solas, M. T., \& Borderías, A. J. (2007b). Technological implications of addition of wheat dietary fibre to giant squid (Dosidicus gigas) surimi gels. Journal of Food Engineering, 81(2), 404-411. http:// dx.doi.org/10.1016/j.jfoodeng.2006.11.015.

Statistical Analysis System Institute - SAS. (1999). SAS/STAT user's guide. Cary: SAS Institute.

Schmiele, M., Mascarenhas, M. C. C. N., Barretto, A. C. S., \& Pollonio, M. A. R. (2015). Dietary fiber as fat substitute in emulsified and cooked meat model system. LWT - Food Science and Technology, 61(1), 105-111. http://dx.doi.org/10.1016/j.lwt.2014.11.037

Steenblock, R., Sebranek, J. G., Olson, D. G., \& Love, J. A. (2001). The effects of oat fiber on the properties of light bologna and fat-free frankfurters. Journal of Food Science, 66(9), 1409-1415. http://dx.doi. org/10.1111/j.1365-2621.2001.tb15223.x.
Talukder, S. (2015). Effect of dietary fiber on properties and acceptance of meat products: a review. Critical Reviews in Food Science and Nutrition, 55(7), 1005-1011. http://dx.doi.org/10.1080/10408398. 2012.682230. PMid:24915339

Totosaus, A., \& Pérez-Chabela, M. L. (2009). Textural properties and microstructure of low-fat and sodium-reduced meat batters formulated with gellan gum and dicationic salts. FWT-Food Science and Technology, 42(2), 563-569.

Troy, D. J., Desmond, E. M., \& Buckley, D. J. (1999). Eating quality of low fat beef burgers containing fat-replacing functional blends. Journal of the Science of Food and Agriculture, 79(4), 507-516. http:// dx.doi.org/10.1002/(SICI)1097-0010(19990315)79:4<507::AIDJSFA209>3.0.CO;2-6.

Turhan, S., Sagir, I., \& Sule Ustun, N. (2005). Utilization of hazelnut pellicle in low-fat beef burgers. Meat Science, 71(2), 312-316. http:// dx.doi.org/10.1016/j.meatsci.2005.03.027. PMid:22064231

Warner, K., \& Inglett, G. (1997). Flavor and texture characteristics of foods containing Z-trim corn and oat fibers as fat and flour replace. Cereal Food World, 42(10), 821-825.

Yang, H. S., Choi, S. G., Jeon, J. T., Park, G. B., \& Joo, S. T. (2007). Textural and sensory properties of low fat pork sausages with added hydrated oatmeal and tofu as texture-modifying agents. Meat Science, 75(2), 283-289. http://dx.doi.org/10.1016/j.meatsci.2006.07.013. PMid:22063660 